\title{
The Implementation of Authentic Assessment in English Language Teaching
}

\section{Indriyana Saputri, Joko Nurkamto, Dewi Sri Wahyuni}

\author{
English Education Department \\ Teacher Training and Education Faculty \\ Sebelas Maret University of Surakarta
}

Email: indriyanasaputri.90@gmail.com

\begin{abstract}
This research aims to describe (1) teachers' perceptions toward authentic assessment; (2) the implementation of authentic assessment; and (3) the effects of authentic assessment to the quality of English Language Teaching (ELT). The research method used in this study is qualitative research method, case study. The data were collected through in-depth interview with the teachers and the students, passive classroom observation, and document analysis toward syllabus, lesson plan, scoring rubric. The data were analyzed by using case study data analysis proposed by Yin (2002) consisting of examining, categorizing, tabulating, testing. The next step used in analysing the data was pattern matching. The findings of the research are: (1)teachers' perception toward authentic assessment is assessment which can assess the students' knowledge, skill, and attitude during the teaching and learning process; (2) the implementation of authentic assessment in English language teaching conducted in one of state senior high school in Surakarta includes types of authentic assessment, the steps of developing authentic assessment, documents used in implementing authentic assessment, teachers and students' roles, teachers obstacles in implementing authentic assessment; (3) the implementation of authentic assessment affects to the quality of English language teaching. It can improve students' motivation, interest, self-confidence, activeness, enthusiasm in learning English. The implementation of authentic assessment can also improve the students' English ability and learning result.
\end{abstract}

Keywords: authentic assessment, English language teaching

\section{INTRODUCTION}

Walvoord (2010: 2) defines assessment as the systematic collection of information about student learning, using the time, knowledge, expertise, and resources available, in order to inform decisions that affect student learning. Assessment is one of important aspects in learning process in order that the students can develop their potential because the number of the students who get low score will affect the learning effectiveness (Mulyasa, 2013: 137).

One of assessment models is authentic assessment. Authentic assessment is the assessment which is conducted comprehensively to assess from the input process, and learning output (Permendikbud Number 66 Year 2013). Authentic assessment is needed in teaching and learning process because it does support the students to be active and enthusiastic in order to be better learners.

The teachers use authentic assessment to assess their students during the teaching and learning process. Through authentic assessment, they can assess the students' real ability. They can assess the students' cognitive, affective, and 
psychomotoric aspects in the process of English language teaching. The implementation of authentic assessment is emphasized in this recent curricullum, curriculum 2013. Actually, it have been emphasized since the previous curriculum.

Based on the background study above, the researcher conducted research about the implementation of authentic assessment in English language teaching. The objectives of the study are: (1) to find out and describe teachers' perception toward authentic assessment; (2) to find out and describe the implementation of authentic assessment; (3) to find out and describe the effects of authentic assessment to the quality of English language teaching.

\section{RESEARCH METHODS}

This research is qualitative case study. Wahyuni (2012) put her idea that case study is used to build upon theory, to produce new theory, to dispute or challenge theory, to explain a situation, to provide a basis to apply solutions to situations, to explore, or to describe an object or phenomenon.

The research was conducted one of state senior high School in Surakarta. The sources of the data were events, informants, and documents. The data were collected by doing in-depth interviews with the teachers and the students, passive classroom observation, and document analysis. During the research, the researcher established good rapport to the teachers and the students in order to gather the data she needed.

The data was analyzed by using case study data analysis which is proposed by Yin (2002). Data analysis was done by examining, categorizing, tabulating, testing, or otherwise recombining both quantitative and qualitative evidence. In this research, the researcher did not combine both quantitative and qualitative evidence in analising the data. The analysis processes were started with examining the data from any sources, in this case from the results of interview, classroom observation, and document analysis. After that, the researcher reduced the data. She ignored the unimportant data and only focused on the data which could answer the problem statements. The next step was categorizing the data. In categorizing the data, the researcher categorized the data which had the same topic. Then, she tabulated the data which had been categorized in order that she could analyse by describing and explaining the data easily. The last step is testing the data. The researcher checked the data again.

The next step in analysing the data used by the researcher was patternmatching. The researcher did patternmatching after examining, categorizing, tabulating, and testing the data. In patternmatching, the researcher compared the reseach findings with the literatures or the previous researches she had.

\section{RESEARCH FINDINGS AND DISCUSSION}

The findings which presented are devided into three parts. The findings are about teachers' perception toward authentic assessment; the implementation of authentic assessment; the effect of authentic assessment to the quality of English language teaching.

The first part is about teachers' perception toward authentic assessment. Teachers' perception toward authentic assessment is assessment which can assess the students' knowledge (cognitive), skill (psychomotor), and attitude (affective) during the teaching and learning process. It 
is useful to know the students real ability, what they have learnt, and how they apply their knowledge. English teachers' perception toward authentic assessment almost relevants with the theory proposed by Mueller. Mueller in Nurgiyantoro (2011: 23) defines that authentic assessment is a form of assessment in which students are asked to perform real-world tasks that demonstrate meaningful application of essential knowledge and skill.

Based on the research findings, teachers' perceptions toward authentic assessment are influenced by their experiences, someone's perception, and by reading some references. The teachers join workshop and they ever get information of authentic assessment through joining the workshop. It can shape their perception toward authentic assessment. The teachers' perception toward authentic assessment can be shaped through someone's perception. When they hold MGMP, they can share and discuss some information related to English language teaching. They also ever discuss about authentic assessment in MGMP. So, the teachers who have joined workshop can share the knowledge about it with the other English teachers. Besides, English teachers' perception can be shaped through reading some books they have. As proposed by Muhyadi (1989), the factors which influence individual's perceptions are person who make perception, situation in the form of an object or event, situation in which perception is formed.

However, the researcher found that teachers understanding towards authentic assessment is not always implemented in their English language teaching because of some factors. The factors are the big classes, limited time, and the administration. This is in line with the research paper conducted by Trisanti (2014). In her paper, she states that that the teachers need facilities and extra time to observe and note down all progress of knowledge, attitude, and skills of the students during their learning process either in class or outside. They also think that the school and goverment should think about the works of teacher in the context of big classes like they have as always. From the research findings, although the English teachers have some obstacles in implementing it, they have tried their best to implement authentic assessment in their English class.

English teachers at that school have implemented authentic assessment since the previous curriculum. They try to implement it in their English classroom because they believed that it is very important to be implemented since they can know students' real ability, difficulties or weaknesses, strengths which cannot be assessed through traditional assessment.

The second term discusses the implementation of authentic assessment in English language teaching. There are some authentic assessments types which are implemented by English. The authentic assessments are role play/performing dialogue, discussion and presentation, story telling and writing, essay, debate, teacher observation, peer assessment and self assessment. It is relevant with the theory proposed by O'Malley and Pierce (1996). They propose that authentic assessments types are oral interviews, story or text retelling, writing samples, projects or exhibitions, experiments/demonstrations, constructed-response items, teacher observations, and portfolios. They do not mention self assessment and peer assessment but they have not listed selfassessment as a separate category because it should be involved in all of the types of assessment identified (p. 11). 
The teachers can conduct authentic assessment through those activities. As they explained during the interviews that when they give the students interesting authentic tasks, the students will be attracted in doing the task. The teachers can do authentic assessment during the learning process when the students do the task. They can know and assess how the students work in group, how their responsibility is. Besides, they can know how the students apply their knowledge and know their real ability in English. The teachers stated that they can assess the students ability which cannot be assessed through traditional assessment. It does not mean that they do not conduct traditional assessment anymore in assessing their students, but they use both of them in order that they can complement each other.

The teachers need to design authentic assessment before they implement it in the classroom. The steps of designing or developing authentic assessment are standard setting, determining authentic task, making criteria, and making scoring rubric. Standard setting includes core competence, basic competence, and indicators setting. It is reflected on teachers' syllabus and lesson plan they have made. After that, the teachers determine authentic task. They choose and determine the authentic task which is appropriate for their students and can give the students valuable experience. Then, they make criteria which will be assessed from the authentic task. After making criteria, the teachers stated that they have to make scoring rubric in order that they can assess their students easily. Arends (1998) also indicates that many experts in authentic assessment argue that for authentic assessments to be effective, the criteria and standards for student work must be clear, known, and nonarbitrary.
There are documents used in implementing authentic assessment. They are syllabus, lesson plan, and scoring rubric. The components of the syllabus are core competence, basic competence, subject material, learning activities, assessment, time allocation, and learning resources. After knowing and understanding the core competence and basic competence which are in the syllabus, the teachers make lesson plan. Lesson plan contains core competence, basic competence, indicators, teaching objectives, learning material, learning method, media, tool, learning resources, learning activities, and assessment. The teachers convinced that lesson plan is very important. By arranging lesson plan, they can make the English teaching and learning process run well and effectively.

On that school, the English teaching and learning process in the classroom seems to be different from the activity which has been planned in the lesson plan. The teachers develop it in the field based on the students condition. Besides, preparing lesson plan makes the English teaching and learning process is more organized and still on the right track.

The other document used is scoring rubric. In assessing their students task and performance through authentic assessment, the teachers make and prepare scoring rubric. It is reflected on the lesson plan and scoring rubricthey made. In interview results, the teachers convinced thay by using scoring rubric, they can get easy when they assess their students. They does not get confused because the aspects which will be assessed have been clear. Arends (1998) state that scoring rubrics is one technique assessment experts have derived to make criteria clear and non-arbitrary.

In contrast, the English teachers sometimes do not use scoring rubric they 
made when they asess their students' task and performance. They say that they also have difficulties in using the scoring rubric. The difficulties are related to the limited time and much of the students. Although they have made and prepared the scoring rubric, they do not use it when they assess their students. It is due to the limited time they have. When they face those problems, they assess their students globally without using the scoring rubric. To overcome those problems, the teachers sometimes use the break time to assess their students task and performances.

Teachers and students have significant roles in the implementation of authentic assessment. When they play their roles well, the implementation of authentic assessment will run optimally. Teachers roles are giving motivation, giving feedback, monitoring the students, and as resources. One of teachers roles is giving feedback. The teachers believed that by giving or providing feedback to their students task and performance in authentic assessment is very important. Wiggins (1998) states that if assessment is to improve performance, not just audit it, the techniques of assessment must be accompanied by quality feedback provided to learners. The teachers give feedback after the students perform in front of the class. They stated that by getting feedback, the students can know the result of their task and performance. Besides, the students can maintain and improve their ability and performance. It is relevant with the theory proposed by Wiggins (p. 43). He proposes that helpful feedback enables a performer to revise performance to meet high (yet clear and stable) standards.

The researcher also finds that students role is as active participant in the implementation of authentic assessment. In English language teaching, the teachers also promote their students to give their active participation. When the students give their active participation, they know that they will get additional score from the teachers so that it can affect to their motivation in learning English and learning result. Hijriati (2014) states that the significance of the implementation of authentic assessment in curriculum 2013 implies some solutions for teaching techniques that allow teacher to boost the students' competency and optimize students' participation in learning process.

The last part discusses the effect of authentic assessment to the quality of English language teaching. The implementation of authentic assessment in English language teaching brings some positive effects to the students. It can improve students' motivation, selfconfidence, interest, creativity, active, and enthusiasm. Besides, it can also improve students' English ability and learning result. It is relevant with Goctu (2012), as he reports in his research that portfolio assessment provides a more authentic assessment of students' achievement and comprehensive views of students' performances in context.

Related to students' English ability, this research is in line with Charvade, Jahandar, and Khodabandehlu (2011). In their research, they report that there is a significant difference between the impact of portfolio assessment and traditional assessment on EFL learners' reading comprehension ability and portfolio assessment has a positive effect on EFL learners' reading comprehension ability.

This research also found that authentic assessment can improve the students active participation in English learning process. This research result strengthens the previous research which was 
conducted by Winasis (2010). Her research reports that teaching and learning activity by using STAD and authentic assessment can improve students participation and improve student-concept mastery in teaching and learning process.

Authentic assessment can also improve students motivation in learning English. It is the same with the research result which had been conducted by Balik (2012). His research reports that the implementation of authentic assessment in Mathematics teaching and learning process affect to the students' achievement and motivation.

Overall, the results of this case study suggest that the implementation of authentic assessment strongly influences in improving students' motivation, interest, enthusiasm, active, self confidence, ceativity, English ability, and learning result. For that reason, teachers need to implement authentic assessment in English language teaching by choosing the appropriate types of authentic assessment for their students.

\section{CONCLUSION AND SUGGESTION}

The English teachers who were involved in this research have the same perceptions toward authentic assessment. their perception toward authentic assessment is assessment which can assess the students' knowledge (cognitive), skill (psychomotor), and attitude (affective) during the teaching and learning process. It is useful to know the students real ability and what they know and what they can do. Teachers' perceptions toward authentic assessment are influenced by their experiences, someone's perception, and by reading some references.

There are some types of authentic assessments which were implemented in
English classrooms. The English teachers chose the appropriate types of authentic assessments for their students. Before conducting authentic assessment, there are four steps on developing authentic assessment. They are standard setting, determining authentic task, making criteria, and making rubric. In the implementation of authentic assessment, teachers and students have important roles which have to be done in order that the implementation of authentic assessment can run well. However, the teachers have some obstacles in implementing it. The obstacles are about the administration, limited time, and big classes.

However, the English teachers have tried their best on implementing authentic assessment although they have some obstacles. The implementation of authentic assessment can improve students' participation, motivation, creativity, self confidence, interest in learning English. Besides, authentic assessment can improve students' English ability and learning result.

The researcher gives some suggestions from the result of the study involved the suggestion for school, teachers , students, and future research. Regarding with the school, this research suggests to the policy maker in school such as headmaster to hold and socialize authentic assessment to all teachers. It is expected that all teachers understand and do not confuse how to plan, design, and implement authentic assessment in their own class.

Then, regarding with the teachers, they should have discussion with other English teachers, it can be with the English teachers in the same school or even with the English teachers from other schools. By having discussion, they can share knowledge, experience, and exchange idea about authentic assessment. They can also solve the problems faced when they 
implement authentic assessment. Beside that, teachers should plan, design, and implement authentic assessment well. Moreover, English teachers should choose appropriate types of authentic assessment based on the students' condition or needs and teachers' ability.

Next, regarding with the students, they should be active in participating English learning process when the teachers implement authentic assessment. If the students are active in participating, they will get valuable experiences to develop and optimize their English ability. So, they could improve their learning achievement and motivation.

The last, regarding with the future researcher, it is suggested to conduct research about authentic assessment in specific skills and certain type of authentic assessment. How authentic assessment implemented in that skills by using one of types of authentic assessment, how it affects to students learning result and motivation.

\section{BIBLIOGRAPHY}

Arends, Richard I. (1998). Learning to Teach $4^{\text {th }}$ ed. New York: McGrawHill.

Balik, I Wayan. (2012). Pengaruh Implementasi Asesmen Autentik terhadap Prestasi Belajar Matematika dan Motivasi Berprestasi. Unpublished Thesis: Universitas Pendidikan Ganesha.

Charvade, M. S., Jahandar, S., \& Khodabandehlou, M. (2012). The Impact of Portfolio Assessment on EFL Learners' Reading Comprehension Ability. Canadian
Center of Science and Education, 5 (7), 129-139.

Goctu, Ramzan. (2012). Portfolio Assessment in English Language Teaching. Journal of Education, 1 (1), 23-27.

Hijriati, Hanifatul. (2014). Authentic Assessment and the Implication to Students' Self-Esteem in Teaching English at Senior High School. Proceedings: The $61^{\text {th }}$ TEFLIN International Conference, UNS Solo 2014.

Muhyadi. (1989). Organisasi Teori, Struktur, dan Proses. Jakarta: Depdikbud.

Mulyasa. (2013). Pengembangan dan Implementasi Kurikulum 2013. Bandung: PT. Remaja Rosdakarya.

Nurgiyantoro, Burhan. (2011). Penilaian Otentik Dalam Pembelajaran Bahasa. Yogyakarta: Gadjah Mada University Press.

O' Malley, J. Michael and Pierce, L. V. (1996) Authentic Assessment for English Language Learners: Practical Approaches for Teachers. Addison-Wesley Publishing Company, Inc.

Permendikbud Nomor 66 Tahun 2013 tentang Standar Penilaian Pendidikan

Sri Wahyuni. (2012). Qualitative Research Method: Theory and Practice. Jakarta: Salemba Empat.

Trisanti, Novia. (2014). English Teacher's Perspective on Authentic Assessment Implementation of Curriculum 2013. Proceedings: The 
$61^{\text {th }}$ TEFLIN International

Conference, UNS Solo 2014.

Walvoord, Barbara E. (2010). Assessment Clear and Simple. San Francisco: John Wiley \& Sons, Inc.

Wiggins, Grant P. (1998) Educative Assessment: Designing Assessments to Inform and Improve Student Performance. San Fransisco: Jossey-Bass Publishers.

Winasis, Sulistyowati (2010). Penerapan $\begin{array}{lll}\text { Metode } & \text { Student } & \text { Teams } \\ \text { Achievement } & \text { Divisions } & \text { (STAD) }\end{array}$ Disertai Authentic Assessment untuk Meningkatkan Partisipasi dan Penguasaan Konsep dalam Pembelajaran Biologi. Unpublished Thesis: Universitas Sebelas Maret Surakarta.

Yin, Robert K. (2002). Case Study Research Design and Methods. California: Sage Publication 